\title{
SOME BIOLOGICAL ACTIVITIES OF MALAYSIAN LEECH SALIVA EXTRACT
}

\author{
Abdualrahman M.AbdualkadeR*¹, Ahmed MerzouK*, \\ AbBas MOHAMMEd GHAWI** AND MOHAMMED AlaAMA* \\ * Pharmaceutical Chemistry Department, \\ **Basic Medical Science Department, \\ Kulliyyah of Pharmacy, International Islamic University Malaysia, \\ Jalan Istana 25200, Kuantan, Pahang, Malaysia. \\ Iarmak1983@gmail.com
}

\begin{abstract}
Leeches were fed on the phagostimulatory solution through parafilm membrane. The satiated leeches were forced to regurgitate the solution by soaking them in an ice-container. The anticoagulant activity was ascertained using thrombin time assay (TT). The result revealed that the saliva concentration which increases TT by $100 \%$ $\left(\mathrm{IC}_{100}\right)$ is $43.205 \mu \mathrm{g} / \mathrm{ml}$ plasma. The antimicrobial activity of the saliva was tested against several bacterial spp. (E. coli, P. aeruginosa, B. cereus, Sal. typhi and S. aureus) and fungi spp. (C.albicans and C.neoformans). It was found that saliva has an inhibition activity against Sal. typhi (minimal inhibitory concentration MIC $78.253 \mu \mathrm{g} / \mathrm{ml}$ ), S.aureus (MIC $78.253 \mu \mathrm{g} / \mathrm{ml}$ ) and E .coli (MIC $121.256 \mu \mathrm{g} / \mathrm{ml}$ ).
\end{abstract}

ABSTRAK: Pacat-pacat diberi makan larutan phagostimulatory menerusi membran parafilem. Pacat-pacat yang kekenyangan itu dipaksa memuntahkan larutan tersebut dengan direndam di dalam bekas berisi ais. Aktiviti antigumpal ditentukan menggunakan cerakin masa trombin (TT). Keputusan menunjukkan kepekatan air liur pacat menyebabkan pertambahan TT sebanyak $100 \%\left(\mathrm{IC}_{100}\right)$ iaitu $43.205 \mu \mathrm{g} / \mathrm{ml}$ plasma. Aktiviti antimikrob air liur telah diuji dengan pelbagai jenis bakteria (E. coli, $P$. aeruginosa, B. cereus, Sal. typhi dan S.aureus) dan pelbagai jenis kulat (C. albicans dan C. neoformans). Didapati air liur menghasilkan aktiviti perencatan terhadap Sal.typhi (kepekatan perencat minima (Minimal inhibitory concentration - MIC) $78.253 \mu \mathrm{g} / \mathrm{ml}$ ), $S$. aureus (MIC $78.253 \mu \mathrm{g} / \mathrm{ml})$ dan E. coli (MIC $121.256 \mu \mathrm{g} / \mathrm{ml})$.

KEYWORDS: leech; anticoagulant; thrombin time; antibacterial activity

\section{INTRODUCTION}

Over the years, the extremely hazardous blood and infectious diseases have been of a big concern of many researchers looking for new efficacious remedies and treatments. Besides, leeches have been reputed to have important therapeutic applications in clinical medicine since the beginning of civilization. Clinical usage of leech was outlined in Pharoahs paintings, Roman manuscripts and Arabic Islamic writings [1]. More recently, in the $18^{\text {th }}$ and $19^{\text {th }}$ centuries, leeches have been used for phelobotomy, inflammation remedy, rheumatism, plastic surgery and tissue transplantation $[1,2]$.

Extensive researches had been undertaken during the $20^{\text {th }}$ century to isolate and characterize the active contents from leech saliva, especially peptides and proteins. In addition to the most potent antithrombin agent, hirudin which was previously discovered by Haycraft in 1884 [3], many blood affecting peptides with different mechanisms of action have been identified. For example, calin [4], a platelet adhesion inhibitor, and 
saratin [5], an inhibitor of von Willebrand factor, were both isolated from the European Hirudo medicinalis leech saliva extract. Furthermore, other leech species have been fully investigated and many blood-affecting peptides and proteins have been identified. For instance, potent inhibitors of factor $\mathrm{Xa}(\mathrm{FXa})$ lefaxin and antistasin were isolated from Haementaria depressa and Haementeria officinalis, respectively [6, 7].

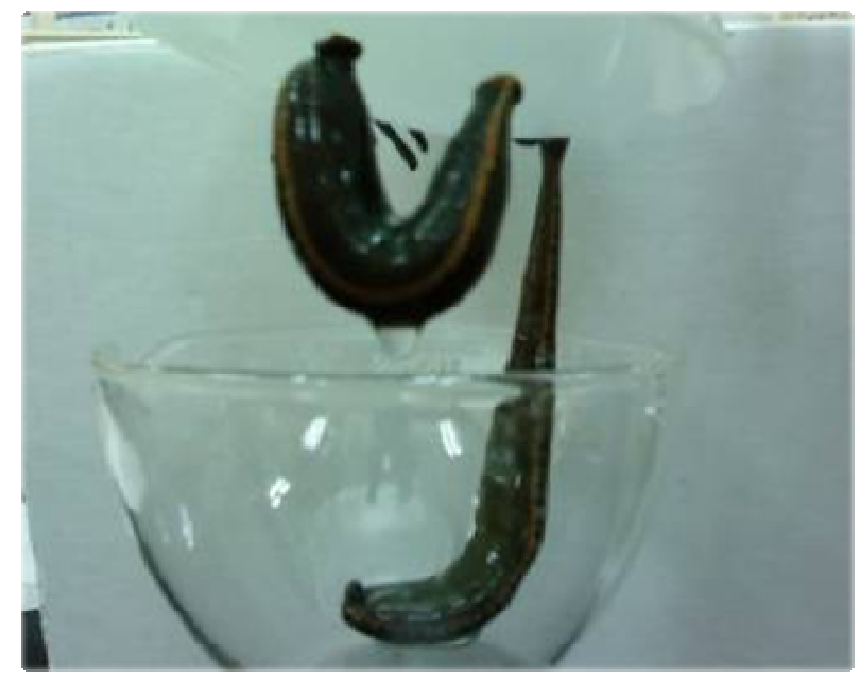

Fig. 1: Feeding leeches on the phagostimulatory solution through parafilm membrane.

On the other hand, two novel antibacterial peptides, theromacin and theromyzin, had been isolated from the coelomic liquid of the leech Theromyzon tessulatum [8].

In Malaysia, leeches have been widely used in traditional therapy for various diseases treatment, but scanty scientific researches were undertaken about medicinal Malaysian leeches [9]. With this concept in mind, the anticoagulant and antimicrobial activity of Malaysian leech saliva have been the subject of this investigation.

\section{MATERIALS AND METHODS}

\subsection{Leeches Sampling and Saliva Collection}

\subsubsection{Leech Sampling}

Leeches were collected by a local supplier from fresh stream water in Kuantan, Pahang, then maintained in well-aerated plastic containers filled with non-chlorated tap water and kept in a separated room at room temperature. Water was regularly changed every two days.

\subsubsection{Leech Feeding}

Starved leech was fed on the phagostimulatory solution of $0.001 \mathrm{M}$ arginine in 0.15 $\mathrm{M}$ sodium chloride warmed at the desired temperature $\left(37^{\circ} \mathrm{C}\right)$ [10]. Then, a glass funnel was wrapped with parafilm sheets and filled with the phagostimulatory solution (Fig. 1) [11]. Thence, leech was brought nearby the parafilm and let to attach itself to it until the leech drops spontaneously.

\subsubsection{Extraction}

After the leech became fully satiated and detached itself from the parafilm, it was kept in a well-closed plastic test tube immersed in an ice container. After an incubation 
period of 15-20 min in ice, the leech became completely paralyzed and regurgitated all the solution it had already sucked. Then, leech was squeezed from the posterior end forwards in order to get out the remaining sucked solution. Last, the used leeches regained their activity by immersing them in warm water $\left(37^{\circ} \mathrm{C}\right)$ for $15-30 \mathrm{~min}$.

Only the colorless fluids were pooled, filtered through $0.45 \mu \mathrm{m}$ Sartorius ${ }^{\circledR}$ filter paper and then centrifuged at $4^{\circ} \mathrm{C}$ for $10 \mathrm{~min}$ at $3000 \mathrm{rpm}$. The resulted fluids were named the crude saliva extract, and only the fresh crude was used during the experiments, unless stated otherwise.

\subsection{Microbial Strains}

Reference strains of human pathogens were used including Gram-positive bacterial spp. (Bacillus cerues ATCC25923 and Staphylococcus aureus ATCC25923), Gramnegative bacterial strains (Pseudomonas aeruginosa ATCC27853, Escherichia coli ATCC35218 and Salmonella typhi from Institute for Medical Research (IMR), Ministry of Health, Malaysia) and two fungal strains (Candida albicans ATCC10231 and Cryptococcus neoformans ATCC90112).

\subsection{Chemicals and Reagents}

Parafilm was the product of American Can Company. Bovine serum albumin (BSA) and arginine were purchased from Sigma Aldrich. Merck was the producer of sodium chloride. In addition, Bradford reagent kit was obtained from Amresco Inc. Thromboclotin $^{\circledR}$ (thrombin reagent) and Control $\mathrm{N}^{\circledR}$ (control plasma) were purchased from Siemens Healthcare Diagnostic. Finally, Mueller-Hinton agar (MHA) and Mueller-Hinton broth (MHB) were purchased from Oxoid Ltd., whereas potato dextrose agar (PDA) and potato dextrose broth (PDB) were purchased from Liofilchem. Distilled water was used to prepare all solvents and solutions during all experiments.

\subsection{Total Protein Estimation}

The total protein concentration of the crude saliva extract was estimated using Bradford assay procedures with bovine serum albumin (BSA) as a standard [12]. All procedures were performed according to Amresco Bradford reagent method, with a small modification including the usage of the phagostimulatory solution as a blank instead of $0.15 \mathrm{M}$ sodium chloride.

A series of standard solutions of BSA and three dilutions of the unknown crude saliva extract were prepared. And their $\mathrm{A}_{595}$ were measured in the presence of Bradford reagent using Infinite M200, NanoQuant TECAN multi detection microplate reader.

\subsection{Antithrombin Activity in vitro}

The antithrombin activity was determined by thrombin time (TT) assay in vitro according to [13] and Thromboclotin ${ }^{\circledR}$ (thrombin reagent) manual using Sysmex CA-50 coagulation analyzer.

\subsubsection{Citrated Plasma Preparation}

Fresh human blood $(4.5 \mathrm{ml})$ taken by venepuncture was mixed with sodium citrate in a citrate tube containing $0.5 \mathrm{ml}$ of $0.11 \mathrm{~mol} / \mathrm{l}$ sodium citrate $(9$ parts of blood : 1 part of sodium citrate) and then centrifuged at $3000 \mathrm{rpm}$ and at room temperature for $10 \mathrm{~min}$. The supernatant citrated plasma was taken and kept at $15-25^{\circ} \mathrm{C}$ to be used within four hours. 


\subsubsection{Thrombin Reagent Preparation}

One vial of thrombin reagent $\left(\right.$ Thromboclotin $^{\circledR}$ ) was reconstituted with $10 \mathrm{ml}$ distilled water. The resulted solution contains $2.5 \mathrm{NIHU}$ thrombin $/ \mathrm{ml}$ and is stable for one week at $2-8^{\circ} \mathrm{C}$ (according to thromboclotin ${ }^{\circledR}$ manual).

\subsubsection{Control Plasma Preparation}

One vial control plasma $\left(\right.$ Control $\mathrm{N}^{\circledR}$ ) was dissolved in $1.0 \mathrm{ml}$ distilled water, shaken gently and let to stand for $15 \mathrm{~min}$ at $15-25^{\circ} \mathrm{C}$. The reconstituted plasma is stable for 4 weeks at $-20^{\circ} \mathrm{C}$ (according Control $\mathrm{N}^{\circledR}$ manual).

\subsubsection{Thrombin Time Assay}

An aliquot $100 \mu 1$ of citrated plasma was pipetted into a pre-warmed coagulation tube provided with the coagulometer and subsequently incubated at $37^{\circ} \mathrm{C}$ in the coagulation analyzer well for $3 \mathrm{~min}$. Then, $10 \mu \mathrm{l}$ of the reconstituted thrombin reagent was added and the time until the coagulation starts was measured by the coagulometer. Different dilutions of the crude saliva extract were mixed with the citrated plasma to yield a final volume of $100 \mu \mathrm{l}$ and TT of the mixtures were measured as mentioned above. A control plasma test was always run before each experiment to evaluate the precision and accuracy of the reagents and the coagulation analyzer.

\subsection{Antimicrobial Activity}

\subsubsection{Disc Diffusion Test}

Disc diffusion test was employed for the determination the anticipated antimicrobial activity of the crude saliva extract as previously stated in [14] with some modifications with the incubation period.

\subsubsection{Microdilution Method}

Microdilution method was performed as described in [14] with some modifications with the incubation period to detrmine the minimal inhibitory concentration (MIC) which is the lowest concentration of the crude saliva extract that can inhibit the growth of a test organism.

To fulfill the experiment, serial double-fold dilutions from the crude saliva extract were carried out in a sterile 96-well plate. Briefy, $100 \mu 1$ of sterile Meuller-Hinton broth was pipetted into the first four columns wells of the plate. Then, $100 \mu 1$ of the crude saliva extract was mixed with the broth in the first four wells of the first row of the plate. Then, dilutions were made by transferring $100-\mu \mathrm{l}$ aliquots of the mixture from the first four wells into the next four ones vertically, and so forth. Subsquently, $10 \mu 1$ of the test organism $\left(10^{7} \mathrm{CFU} / \mathrm{ml}\right)$ was pipetted into each well of the first three columns and the plate was covered and incubated for 24 hours at $37^{\circ} \mathrm{C}$ [14].

\section{RESULTS}

\subsection{Saliva Collection}

The crude saliva extract collected from many leeches were presented in Table 1.

\subsection{Total Protein Assay}

The total protein concentration of the crude saliva extract was estimated by plotting the $\mathrm{A}_{595}$ values of the BSA standard solutions as a function of their concentrations using Microsoft Excel 2007. 
Table 1: The crude saliva extract collected from the starved leeches.

\begin{tabular}{lccc}
\hline No. & $\begin{array}{c}\text { Starvation period } \\
(\text { weeks })\end{array}$ & $\begin{array}{c}\text { Collected volume } \\
(\mathrm{ml})\end{array}$ & $\mathrm{pH}$ \\
\hline Group 1 & 14 & 17 & 6.45 \\
Group 2 & 20 & 13 & 6.37 \\
Group 3 & 23 & 6.5 & 6.39 \\
Group 4 & 25 & 15 & 6.44 \\
\hline
\end{tabular}

The total protein concentration of the crude saliva extract collected from the group 2 was $79.962 \pm 3.213 \mu \mathrm{g} / \mathrm{ml}$. Whereas, group 3 saliva had a total protein concentration of $62.602 \pm 2.517 \mu \mathrm{g} / \mathrm{ml}$. All measurments were repeated in triplicates and the mean \pm standard deviation were considered.

\subsection{Antithrombin Activity in vitro}

The crude saliva extract collected from group 2 was the subject of the antithrombin activity assay. Results revealed that the antithrombin activity (TT prolongation) of the crude saliva extract was a linear function with the volume of the crude mixed with the citrated plasma. Accordingly, the concentration of saliva in $\mu \mathrm{g} / \mathrm{ml}$ which increases the TT by $100 \%\left(\mathrm{IC}_{100}\right)$ can be calculated from the curve drawn from plotting saliva volumes $(\mu \mathrm{l})$ versus thrombin time (sec). See Fig. 2 and Table 2.

Consequently, it was found that $54.033 \mu 1$ of the crude saliva extract can increase TT by two-folds, corresponding to an $\mathrm{IC}_{100}$ of $43.205 \mu \mathrm{g} / \mathrm{ml}$ plasma.

\subsection{Antimicrobial Activity}

The antibacterial and antifungal activities of the fresh crude saliva extract and the lyophilized saliva collected from leech group 1,3 and 4 are presented in Table 3.

Notably, the results showed that the fresh crude saliva extract collected after a starvation period of 14 weeks has a remarkable inhibitory activity against at least one of the test organisms (Table 3). Whereas, neither the fresh crude saliva extract collected from leeches starved for 23 weeks nor the ten-folds concentration of the lyophilized saliva extract collected after 25 weeks of starvation exhibited antimicrobial activity.

MIC of the lyophilized concentrated saliva extract which showed antibacterial activity against $S$. aureus and Sal. typhi was $78.253 \mu \mathrm{g} / \mathrm{ml}$. Whereas, MIC of the saliva which possessed inhibition activity against $E$. coli was $121.256 \mu \mathrm{g} / \mathrm{ml}$. 
IIUM Engineering Journal, Vol. 12, No. 4, 2011: Special Issue on Biotechnology

AbdualKader et al.

Table 2: The anticoagulant (antithrombin) activity of the crude saliva extract.

\begin{tabular}{lcc}
\hline Sample & Volume & $\begin{array}{c}\text { Thrombin } \\
\text { time }\end{array}$ \\
\hline Control N $^{\circledR}$ & 100 & $17.10 \pm 1.97^{\mathrm{a}}$ \\
Citrated plasma & 100 & $16.57 \pm 0.90$ \\
Blank (Arg+NaCl) & 70 & $17.30 \pm 1.20$ \\
Distilled water & 70 & $17.97 \pm 0.99$ \\
Crude saliva extract (group 2) & 30 & $22.43 \pm 1.92$ \\
& 50 & $30.57 \pm 2.73$ \\
& 60 & $35.17 \pm 0.90$ \\
& 70 & $41.43 \pm 1.36$ \\
\hline
\end{tabular}

${ }^{\text {a }}$ results are expressed as the mean of triplicates \pm standard deviation SD.
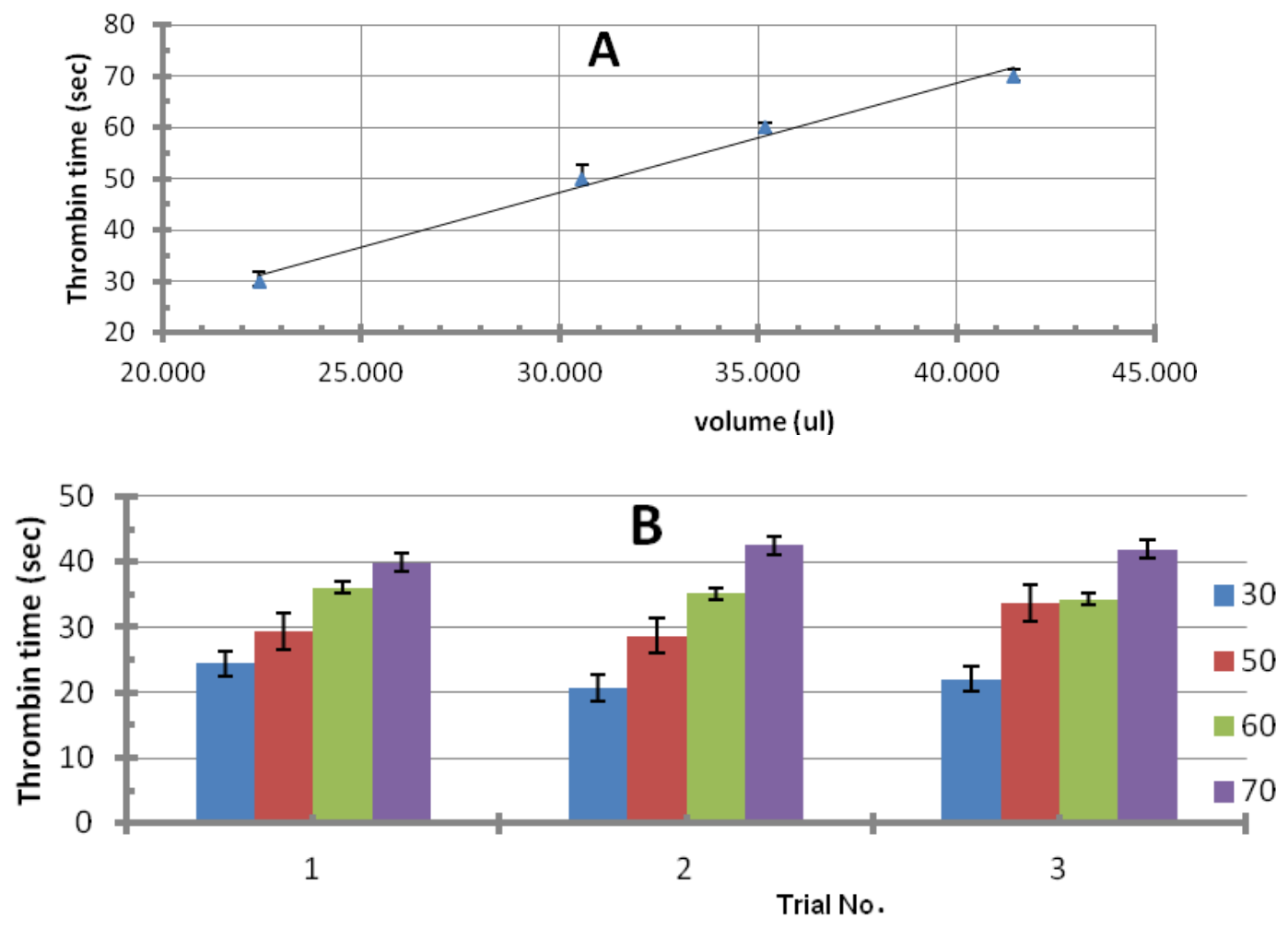

Fig. 2. A: The anticoagulant activity of crude saliva extract. The volume which duplicates TT was $54.033 \mu \mathrm{l}$. So, $\mathrm{IC}_{100}=43.205 \mu \mathrm{g} / \mathrm{ml}$ plasma. All values are the mean of triplicates \pm SD. $\mathrm{R}^{2}=0.989, \mathrm{y}=2.123 \mathrm{x}-16.31$, where $\mathrm{y}=$ thrombin time $(\mathrm{sec})$ and $\mathrm{x}=$ volume

$(\mu 1)$. B: Thrombin time of the crude saliva extract and citrated plasma mixture in triplicates. 
IIUM Engineering Journal, Vol. 12, No. 4, 2011: Special Issue on Biotechnology

AbdualKader et al.

Table 3: The antimicrobial activity of the fresh and the lyophilized concentrated crude saliva extract.

\begin{tabular}{|c|c|c|c|c|c|c|c|c|}
\hline \multirow{3}{*}{ Sample } & \multirow{3}{*}{$\begin{array}{l}\text { Starvation } \\
\text { period }\end{array}$} & \multicolumn{5}{|c|}{ Bacterial spp. } & \multicolumn{2}{|c|}{ Fungal spp. } \\
\hline & & S. aureus & P. auroginosa & Sal. typhi & E. coli & B. cereus & $\begin{array}{c}C . \\
\text { albicans }\end{array}$ & C. neoformans \\
\hline & & \multicolumn{7}{|c|}{ Zone of inhibition (mm) } \\
\hline \multirow{3}{*}{ Fresh saliva } & 14 & - & 0 & 22 & 25 & 0 & - & - \\
\hline & 23 & 0 & 0 & 0 & 0 & 0 & - & - \\
\hline & 25 & 0 & 0 & 0 & 0 & 0 & - & - \\
\hline \multirow{2}{*}{ Lyophilized saliva } & $23^{\mathrm{a}}$ & 11 & 0 & 10 & 0 & 0 & 0 & 0 \\
\hline & $25^{\mathrm{b}}$ & 0 & 0 & 0 & 0 & 0 & 0 & 0 \\
\hline Arginin $+\mathrm{NaCl}^{\mathrm{c}}$ & - & - & 0 & 0 & 0 & 0 & 0 & 0 \\
\hline Ciprofolxacin $(5 \mu \mathrm{g})^{\mathrm{d}}$ & - & - & 24 & 35 & 26 & 28 & - & - \\
\hline Nystatin (100units) & - & - & - & - & - & - & 10 & 9 \\
\hline
\end{tabular}

${ }^{\mathrm{a}}$ five folds concentrated, ${ }^{\mathrm{b}}$ ten folds concentrated, ${ }^{\mathrm{c}}$ the phagostimulatory solution as negative control, ${ }^{\mathrm{d}, \mathrm{e}}$ reference antibiotics 0 : no inhibition, -: not determined 


\section{DISCUSSION}

The wide biodiversity of leech species all over the world has led to set up many researches focusing on the anticoagulant and antimicrobial activity of their salivary gland secretion.

Of the leech salivary gland secretion, the European Hirudo medicinalis saliva was known to contain the most potent natural thrombin inhibitor, Hirudin [15, 16]. Additionally, other hirudin-like inhibitors were isolated from other leech species, such as bufrudin and hirullin from Hirudinaria manillensis and haemadin from the Indian leech Haemadipsa sylvestris [16]. Results revealed that the Malaysian leeches exhibited an antithrombin activity since it prolonged TT in a linear dose dependent manner with an apparent inhibition constant $(\mathrm{K})$ of about 2.123 . Remarkably, the $\mathrm{IC}_{100}(43.205 \mu \mathrm{g} / \mathrm{ml})$ represented about $50 \%$ of the total protein content $(79.962 \mu \mathrm{g} / \mathrm{ml})$, indicating that the antithrombin components are a major component of the Malaysian leech crude saliva extract.

In addition of having an anticoagulant activity, the Malaysian leech saliva extract revealed a broad spectrum antibacterial activity against both Gram-positive (S.aureus) and Gram-negative (Sal. typhi and E. coli) bacterial strains, whereas no inhibition was observed against any of the test fungi. In contrast, theromacin and theromyzin isolated from the leech Theromyzon tessulatum showed inhibitory activity directly against Grampositive rather than Gram-negative spp. [8], leading to deduce that the active peptides of Malaysian leech saliva extract are maybe of a different nature.

Importantly, the inactive fresh crude saliva extract examined against the active lyophilized concentrated crude saliva leads to conclude that the antibacterial ingredients are minor components of the crude saliva extract. Furthermore, starvation period seems likely to be an important factor affecting the antibacterial activity of leech saliva extract, and six months of starvation will totally exhaust leeches.

\section{CONCLUSION}

The results reported here suggest that the Malaysian leech saliva extract possesses a similar antithrombin activity to that of the European specie, raising the question of the actual structure of the active peptide, whether it has similarity with the other known antithrombin agents or not. As well, Malaysian leech saliva extract seems to contain broad spectrum antibacterial peptides which are supposed to have a novel structure that needs to be investigated.

\section{ACKNOWLEDGEMENT}

This research was supported gratefully by the grant (EDW B 10-0393) from ResearchManagement Center, International Islamic University Malaysia, IIUM.

\section{REFERENCES}

[1] I.S. Whitaker, J. Rao, D. Izadi and P.E. Butler, "Historical article: Hirudo medicinalis: ancient origins of, and trends in the use of medicinal leeches throughout history," British Journal of Oral and Maxillofacial Surgery. Vol. 42, pp. 133-137, 2004. 
[2] P. Ascenzi, G. Amiconi, B. Wolfram, W. Bode, M. Bolognesi, M. Coletta and E. Menegatti, "Proteinase inhibitor from the European medicinal leech Hirudo medicinalis structure functional and biomedical aspects". Molecular Aspects of Medicine. Vol. 16, pp. 215-313, 1995.

[3] J. Haycraft, "On the action of secretion obtained from the medicinal leech on coagulation of the blood". Proceedings of the Royal Society of London. Vol. 36, pp. 478-487, 1884.

[4] H. Deckmyn, J.M. Stassen, I. Vreys, E. Van Houte, R.T. Sawyer and J. Vermylen, "Calin from Hirudo medicinalis, an inhibitor of platelet adhesion to collagen, prevents platelet-rich thrombosis in hamsters," Blood. Vol. 85, pp. 712-713, 1995.

[5] W. Gronwald, J. Bomke, T. Maurer, B. Domogalla, F. Huber, F. Schumann, W. Kremer, F. Fink, T. Rysiok, M. Frech and H. Kalbitzer, "Structure of the leech protein saratin and characterization of its binding to collagen". J. Mol. Biol. Vol. 381, pp. 913-927, 2008.

[6] G.P. Tuszynski, T.B. Gasic and G.J. Gasic, "Isolation and characterization of antistasin. An inhibitor of metastasis and coagulation," J. Biol. Chem. Vol. 262, no. 20, pp. 9718-23, 1987.

[7] F. Faria, E. Kelen, C. Sampaio, C. Bon, N. Duval and A. Chudzinski-Tavassi, "A new factor Xa inhibitor (lefaxin) from the Haementeria depressa leech," Thromb Haemost. Vol. 82, pp. 1469-1473, 1999.

[8] A. Tasiemski, F. Vandenbulcke, G. Mitta, J. Lemoine, C. Lefebvre, P. Sautière and M. Salzet, "Molecular characterization of two novel antibacterial peptides inducible upon bacterial challenge in an annelid the leech Theromyzon tessulatum," The Journal of biological Chemistry. Vol. 279, No. 30, pp. 30973-30982, 2004.

[9] C. Yule and Y. Sen, Freshwater Invertebrates of th Malaysian Region, Malaysia: Akademi Sains Malaysia.

[10] M. Rigbi, H. Levy, F. Iraqi, M. Teitelbaum, M. Orevi, A. Alajoutsijärvi, A. Horovitz and R. Galun, "The saliva of the medicinal leech Hirudo medicinalis-I. Biochemical characterization of the high molecular weight fraction". Comp. Biochem. Physiol. Vol. 87B, No. 3, pp. 567- 573, 1987.

[11] M. Dickinson and C. Lent, "Feeding behavior of the medicinal leech Hirudo medicinalis L". J. Copm Physiol A. Vol. 154, pp. 449-455, 1984.

[12] M.M. Bradford, "A rapid and sensitive method for the quantitation of microgram quantities of protein utilizing the principle of protein-dye binding". Analytical Biochemistry. Vol. 72, pp. 248-254, 1976.

[13] B. Schmied, H. Hoeffken, W. Hornberger and H. Bernard, "Peptides with anticoagulant activity". United States Patents. Patent Number 5,393,873, 1995.

[14] M.B. Coyle, Manual of Antimicrobial Susceptibility Testing, American Society for Microbiology.

[15] F. Markwardt, "The development of hirudin as an antithrombin drug," Thromb. Res. Vol. 74, pp. 1-23, 1994.

[16] C. Koh and M. Kini, "Molecular diversity of anticoagulants from haematophagous animals". Thromb. Haemost. Vol. 102, pp. 437-453, 2009. 